\title{
Jurgen Woerdman
}

Functie/organisatie: lid raad van bestuur Saltro Diagnostisch Centrum Utrecht

Sport: wielrennen

Opvallendste prestatie: "Een aantal keren de strandrace Hoek van Holland-Den Helder uitgereden, op de mountainbike. Vind ik een mooie prestatie, want die race is behoorlijk zwaar."

\section{Waarom wielrennen?}

"Vijftien jaar geleden maakte ik tijdens het skië stevige val. Toen kwam ik erachter dat mijn conditi kort schoot en ben op een oude racefiets gestapt. Dat is uit de hand gelopen, want het is de enige sport die ik nog beoefen, naast het skiën. Ik rij zo'n zes- tot achtduizend kilometer per jaar. Eerst op tweedehandsjes, inmiddels heb ik mijn vijfde fiets. Ze worden steeds mooier."

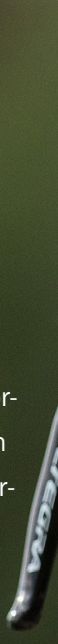

\section{Wat is de lol?}

"Sowieso het fysieke. En ik word nog steeds beter, raar genoeg, maar dat komt doordat ik laat begonnen ben en dan kun je je nog steeds verbeteren: ik maak langere tochten, ga steeds sneller. Elke zondag rij ik met een groepje van vijftien à twintig vrienden, allemaal vijftigplussers die al hun leven lang fietsen. Eerst werd ik eraf gereden, steeds vaker kan ik voorin meedraaien. Dat is leuk."

4. En andersom?

“Wanneer we een nieuw gezicht in de groep hebben, oordeel ik soms te snel: kan die wel meekomen? Dat blijkt vaak anders uit te pakken. Dat is echt een les voor mij als bestuurder: achter ieder mens zit een ander verhaal, geef jezelf de tijd om je oordeel te vormen."

\section{(1)}

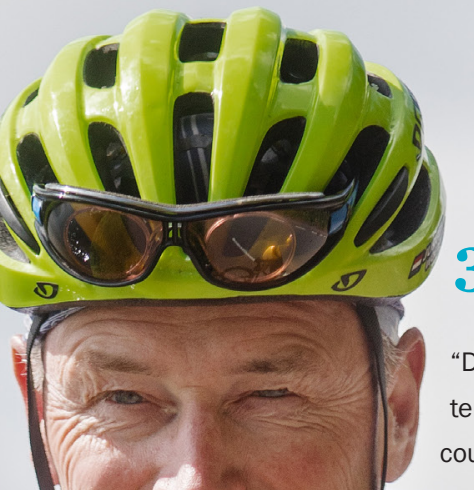

3. Leert de bestuurder van de fietser?

“Daar kan ik talloze wielermetaforen op loslaten, maar de belangrijkste les voor mij is: parcourskennis is alles. Ook aan de bestuurstafel moet je je goed voorbereiden. En net zoals ik mezelf moet oppeppen als ik slechte benen heb, spreek ik mezelf soms ook als bestuurder toe op momenten dat ik denk: dit gaat het niet worden. Dan pik je toch aan en voltooi je de race." 